\title{
Comment on unplanned out-of-hospital birth and risk factors of adverse perinatal outcome: findings from a prospective cohort
}

\author{
Razieh Bidhendi Yarandi ${ }^{1,2}$ and Mohammad Hossein Panahi ${ }^{{ }^{*}}$
}

\begin{abstract}
The aim of this Letter to the Editor was to report some methodological shortcomings in a recently published Article. We proved that the obtained results are subjected to the sparse data bias and presented some remedial tools such as penalization approaches. In addition, model fitting and performance aroused some controversies. In conclusion, the results of this study should be interpreted with caution and further reanalysis is necessary.
\end{abstract}

Keywords: Internal validity, Methodology, Predictive factors, Prediction modelling, Sparse data bias

\section{Dear Editor,}

We read with great interest the recent paper by François Javaudin et.al published in the Scandinavian Journal of Trauma, Resuscitation and Emergency Medicine entitled "Unplanned out-of-hospital birth and risk factors of adverse perinatal outcome: findings from a prospective cohort" [1]. The purpose of their study was to describe neonatal morbidity and mortality, defined as death or neonatal intensive care unit hospitalization at Day 7, in a large and multicenter cohort of unplanned out-of-hospital births. Some methodological problems were mentioned in this note.

Firstly, it was not clear how predictor variables for multiple logistic regression were selected. One of the routine approaches is to select confounder variables based on a univariate model with a $p$-values less than 0.2 or 0.5 to prevent overfitting. Another approaches are directed acyclic graph, bootstrap and Bayesian model averaging.

Secondly, the authors reported multiparity as an independent predictive factor of neonatal morbidity and mortality (adjusted Odds Ratio $=70.7 \quad[95 \%$ Confidence Interval: 4.7-1062]). A very big odds ratio with an

\footnotetext{
* Correspondence: mohammadpanahi55@yahoo.com

1 Department of Epidemiology and Biostatistics, School of Public Health,

Tehran University of Medical Sciences, Tehran, Iran

Full list of author information is available at the end of the article
}

extremely wide confidence interval proves the existence of the sparse data bias. The authors could use penalization methods such as data augmentation and Firth to resolve this problem [2-4]. Also in this study prematurity, maternal pathology and hypothermia reported as the independent predictive factors of neonatal morbidity and mortality. In fact, this conclusion is optimistic without the Internal Validity checking. Several approaches are presented for checking Internal Validity models such as split-sample validation, cross-validation and bootstrapping [5].

We suggest author provide more reliable results by the unbiased estimates and internal validity of predictors.

\section{Acknowledgements \\ Not applicable. \\ Funding \\ No funding. \\ Availability of data and materials Not applicable.}

\section{Authors' contributions}

This letter was written by MHP, RBY. MHP investigated and supervised this work. All authors read and approved the final manuscript.

\section{Ethics approval and consent to participate Not applicable.}

\section{Consent for publication}

Not applicable. 


\section{Competing interests}

The authors declare that they have no competing interests.

\section{Publisher's Note}

Springer Nature remains neutral with regard to jurisdictional claims in published maps and institutional affiliations.

\section{Author details}

'Department of Epidemiology and Biostatistics, School of Public Health Tehran University of Medical Sciences, Tehran, Iran. ${ }^{2}$ Reproductive Endocrinology Research Center, Research Institute for Endocrine Sciences, Shahid Beheshti University of Medical Sciences, Tehran, Iran.

Received: 25 March 2019 Accepted: 29 March 2019

Published online: 05 April 2019

\section{References}

1. Javaudin F, Hamel V, Legrand A, Goddet S, Templier F, Potiron C, Pes P, Bagou G, Montassier E. Unplanned out-of-hospital birth and risk factors of adverse perinatal outcome: findings from a prospective cohort. Scandinavian journal of trauma, resuscitation and emergency medicine. 2019 Dec;27(1):26.

2. Firth D. Bias reduction of maximum likelihood estimates. Biometrika. 1993; 80(1):27-38.

3. Firth D. Recent developments in quasi-likelihood methods. Bulletin of the international Statistical Institute. 1993:55:341-58.

4. Heinze G, Schemper M. A solution to the problem of separation in logistic regression. Stat Med. 2002;21(16):2409-19.

5. Steyerberg E. Clinical prediction models: a practical approach to development, validation and updating: Springer Science \& Business Media; 2008

Ready to submit your research? Choose BMC and benefit from:

- fast, convenient online submission

- thorough peer review by experienced researchers in your field

- rapid publication on acceptance

- support for research data, including large and complex data types

- gold Open Access which fosters wider collaboration and increased citations

- maximum visibility for your research: over $100 \mathrm{M}$ website views per year

At $\mathrm{BMC}$, research is always in progress. 